\title{
Co-inoculation with diazotrophic bacteria in soybeans associated to urea topdressing
}

\author{
Co-inoculação com bactérias diazotróficas em soja associada a \\ aplicação de ureia em cobertura
}

\author{
Glauber Monçon Fipke ${ }^{1 *}$, Gerusa Massuquini Conceição², Luiz Fernando Teleken Grando², \\ Rodrigo Luiz Ludwig², Ubirajara Russi Nunes², Thomas Newton Martin²
}

\author{
${ }^{1}$ Universidade Federal de Santa Maria/UFSM, Departamento de Fitotecnia, Santa Maria, RS, Brasi \\ Universidade Federal de Santa Maria/UFSM, Santa Maria, RS, Brasil \\ *Corresponding author: gm.fipke@hotmail.com \\ Received in January 11, 2016 and approved in July 27, 2016
}

\begin{abstract}
Increased grain yield can be obtained via an interaction between plants and growth-promoting microorganisms. The Bradyrhizobium spp. are capable of fixing atmospheric nitrogen in soybeans [Glycine max (L.) Merril], and Azospirillum spp. induce the synthesis of phytohormones. The aim of this study was to evaluate inoculation with Bradyrhizobium and co-inoculation with Bradyrhizobium + Azospirillum brasilense in soybeans in combination with the application a topdressing of 0,75 or $150 \mathrm{~kg}$ of $\mathrm{N} \mathrm{ha}^{-1}$ of urea during the reproductive stage. Three soybean cultivars (BMX Ativa, TEC 6029 and BMX Potência), were tested in field experiments in Santa Maria, RS, Brazil, during two agricultural years (2013/2014 and 2014/2015) and two sowing times. Morphological, nodulation and yield components were evaluated. Co-inoculation increased the grain yield by $240 \mathrm{~kg} \mathrm{ha}^{-1}$ compared with conventional inoculation. When co-inoculated, cultivars BMX Ativa, TEC 6029 and BMX Potência showed increased grain yields of 6, 4 and 12\%, respectively. The application of $150 \mathrm{~kg} \mathrm{ha}^{-1}$ of N as a topdressing increased the grain yield by $300 \mathrm{~kg} \mathrm{ha}^{-1}$ in the co-inoculated cultivars TEC 6029 and BMX Potência, but without a financial return. When inoculated only with Bradyrhizobium, the cultivars did not respond positively to the application of urea.
\end{abstract}

Index terms: Azospirillum spp.; Bradyrhizobium spp.; Glicine max (L.) Merr.; nitrogen.

\begin{abstract}
RESUMO
O incremento na produtividade de grãos pode ser obtido pela interação entre plantas e microrganismos promotores do crescimento vegetal. Bactérias do gênero Bradyrhizobium spp. são capazes de realizar a fixação do nitrogênio em soja [Glycine max (L.) Merril], enquanto as do gênero Azospirillum spp. induzem a síntese de hormônios vegetais. O objetivo do presente trabalho foi avaliar a inoculação com Bradyrhizobium e co-inoculação com Bradyrhizobium + Azospirillum brasilense em sementes de soja associado a aplicação de 0, 75 e 150 kg de N ha ${ }^{-1}$ de ureia aplicada em cobertura no estádio reprodutivo. Três cultivares de soja (BMX Ativa, TEC 6029 e BMX Potência) foram utilizadas nos experimentos em Santa Maria, RS, Brasil, durante dois anos agrícolas (2013/2014 e 2014/2015) e duas épocas de cultivo. Foram avaliadas as características morfológicas, de nodulação e componentes da produtividade. A co-inoculação proporcionou incremento de 240 kg de grãos ha-1 em relação a inoculação convencional. Quando co-inoculadas, as cultivares BMX Ativa, TEC 6029 e BMX Potência acresceram a produtividade de grãos em 6,4 e 12\% respectivamente. A aplicação de $150 \mathrm{~kg}$ de N ha-1 acresceu a produtividade em 300 kg de grãos ha-1 ${ }^{-1}$ com a co-inoculação das cultivares TEC 6029 e BMX Potência, porém, sem retorno econômico. Os cultivares testados quando inoculados somente com Bradyrhizobium não responderam positivamente à aplicação de ureia.
\end{abstract}

Termos para indexação: Azospirillum spp.; Bradyrhizobium spp.; Glycine max (L.) Merr.; nitrogênio.

\section{INTRODUCTION}

Inoculation of soybeans with Bradyrhizobium genus (conventional inoculation) is one of the determining factors for achieving high yields because of biological nitrogen fixation (BNF), which is a sustainable source of the nutrient. Typically, the populations of rhizobia naturally present in the soil are low or inefficient for adequate BNF; thus, inoculation is necessary (Santos et al., 2013, Atieno et al., 2012, Deaker et al., 2004). In Brazil, this is a widespread cultural practice that is indicated in the technical recommendation guides of the country's regions, and it contributes to an increase in crop production (Hungria; Nogueira; Araújo, 2015).

Many studies have assessed the plant-microorganism interaction and have shown the potential for the use of plant growth-promoting rhizobacteria (PGPR) for improving the performance of soybean crops (Hayat et al., 2010). This group of microorganisms can benefit the plant via multiple mechanisms, which have been divided into direct 
and indirect stimulation. Direct stimulation mechanisms are BNF in the Fabaceae and Poaceae, the synthesis of plant hormones such as auxin and gibberellins, and the solubilization of minerals such as phosphates. Indirect stimulation mechanisms are the production of antagonists to pests, antibiotics, and siderophores and the induction of systemic resistance (Bashan; Bashan, 2010, Verma et al., 2010).

Azospirillum is an associative PGPR that has shown the capacity for BNF and the synthesis of plant hormones in the Poaceae (Hungria; Nogueira; Araújo, 2013). The association of Azospirillum brasilense bacteria with rhizobia has shown promising results in the Fabaceae family, such as beans and soybeans (Dardanelli et al., 2008, Benintende et al., 2010). Generally, mixed inoculation or co-inoculation improves seed germination, plant growth, root branching and nodulation (Juge et al., 2012) and suggestions have been made that the presence of Azospirillum helps plants to overcome environmental stresses (Chibeba et al., 2015).

Despite positive results obtained with inoculated seeds, some strategies to meet the nutritional needs of the plant are still the subject of speculation, such as the application of a nitrogen $(\mathrm{N})$ fertilizer topdressing (Petter et al., 2012). During the growth and development of soybean crops, there are some critical periods related to $\mathrm{N}$ stemming from BNF. Among these are the reproductive stages R3 [early pod formation (Fehr et al., 1971)] and R5 (early grain filling), which require high levels of photosynthate and may result in nodule senescence. Assuming that the supply of $\mathrm{N}$ in the soil is low, the demand could be supplied via the application of nitrogen fertilizer (Gan et al., 2003).

The aim of this study was to evaluate inoculation with Bradyrhizobium and co-inoculation with Bradyrhizobium + Azospirillum brasilense in soybeans associated with the application of a topdressing of 0,75 or $150 \mathrm{~kg}$ of $\mathrm{N} \mathrm{ha}^{-1}$ as urea during the reproductive stage.

\section{MATERIAL AND METHODS}

Four experiments were conducted in the experimental area of the Department of Plant Science of Santa Maria Federal University, located in the Central Area of the Rio Grande do Sul state in Brazil at $29^{\circ} 43^{\prime} 05^{\prime \prime} \mathrm{S}$ and $53^{\circ} 43^{\prime} 59^{\prime \prime} \mathrm{W}$ at an altitude of $116 \mathrm{~m}$. The soil in this area is classified as Argissolo Vermelho Distrófico típico (Embrapa, 2013) (a sandy clay loam Acrisol in the FAO classification). Soil samples were collected at a depth of $0-20 \mathrm{~cm}$ for chemical characterization and the results were as follows: $\mathrm{pH}$ (water, $1: 1)=5.1$; organic matter $(\%, \mathrm{~m} / \mathrm{v}$ ) $=2.2$; clay $\left(\mathrm{g} \mathrm{kg}^{-1}\right)=230$; phosphorus, P-Mehlich $\left(\mathrm{mg} \mathrm{dm}^{-3}\right)$ $=17.2 ;$ potassium $\left(\mathrm{mg} \mathrm{dm}^{-3}\right)=84.0 ; \mathrm{H}+\mathrm{Al}\left(\mathrm{cmol} \mathrm{dm}^{-3}\right)=$ 7.9; cation-exchange capacity (CEC) $\left(\mathrm{pH} \mathrm{7,} \mathrm{cmol} \mathrm{dm}^{-3}\right)=$ 14.7; bases saturation $(\%)=47.8$. The climate of the area according to the Köppen classification, is type Cfa (Peel; Finlayson; Mcmahon, 2007); a humid subtropical climate, with the mean temperature in the warmest month of $24.8^{\circ} \mathrm{C}$ and $14.1^{\circ} \mathrm{C}$ in the coldest month (Heldwein; Buriol; Streck, 2009). The data are shown in Figure 1 (Inmet, 2005).

Three months before the experiment, the populations of microorganisms naturally present at the experimental site were determined by sampling the soil. The samples were collected, stored on a sterile swab in a tube and sent to a laboratory at Neoprospecta Microbiome Technologies (Florianópolis, SC). A bacterial diversity analysis was performed, estimated by the number of genetic sequences found. The Illumina Misec ${ }^{\circledR}$ DNA sequencing system was used. A total of 1382 traces of bacterial diversity were determined, and $1.69 \times 10^{2}$ traces of Bradyrhizobium spp. were estimated, but no indication of Azospirillum brasilense was found.

During the two years of testing, wheat was sown during the winter and provided a layer of $4 \mathrm{Mg}$ stubble $\mathrm{ha}^{-1}$. Forty days prior to sowing, $1.5 \mathrm{~L}$ glyphosate $(360$ $\mathrm{g} \mathrm{L}^{-1}$ active ingredient, a. i.) ha ${ }^{-1}$ was applied. Two days prior to sowing, phytosanitary treatment of the seeds was conducted with $0.002 \mathrm{~L}$ pyraclostrobin $\left(25 \mathrm{~g} \mathrm{~L}^{-1}\right.$ a. i.) + thiophanate methyl (225 $\mathrm{g} \mathrm{L}^{-1}$ a. i.) and fipronil (250 $\mathrm{g} \mathrm{L}^{-1}$ a. i.) $\mathrm{kg}^{-1}$ of seed. The seeds were allocated into paper packets and stored in a dry place with constant humidity at $25{ }^{\circ} \mathrm{C}$ soon after treatment with fungicides and insecticides. Seed inoculation and co-inoculation were performed two hours prior to sowing. Sowing and base fertilization were conducted mechanically on October 15 and November 18 in the 2013/14 season and October 28 and December 15 in the 2014/15 season. The sowing density was 13 viable seeds per linear meter with a row spacing of $0.45 \mathrm{~m}$, which provided approximately 289,000 plants ha ${ }^{-1}$. Mineral base fertilizers were mixed and placed in the planting furrow at a dose of $150 \mathrm{~kg}$ ha $^{-1}$ triple superphosphate (TSP, $46 \% \mathrm{P}_{2} \mathrm{O}_{5}$ ) $+150 \mathrm{~kg} \mathrm{ha}^{-1}$ potassium chloride $\left(\mathrm{KCl}, 60 \% \mathrm{~K}_{2} \mathrm{O}\right)$.

Micronutrients such as cobalt and molybdenum, which are generally provided via seed treatment, were not applied in this way because the salinity could interfere with the survival of the inoculated bacterial cells (Silva et al., 2011a). To facilitate the symbiosis between the plants and the bacteria, a foliar application of $0.1 \mathrm{~L} \mathrm{ha}^{-1}$ of a 
commercial product containing Co (1.7\%) and Mo (17\%) was performed during vegetative stage V4 (four nodes and three fully developed trifoliate leaves). Pesticides were applied whenever there was an incidence of pests (weeds, insects or diseases), using products recommended for soybean crops.

The experimental design was a randomized block arranged in a factorial design $(3 \times 2 \times 3)$, with four replications. Soybean cultivars were allocated as the first factor, two types of inoculation as the second factor, and three amounts of $\mathrm{N}$ fertilizer topdressing as the third factor. The experimental unit was $7 \mathrm{~m} \mathrm{x} 2.25 \mathrm{~m}$, for a total of $15.75 \mathrm{~m}^{2}$. The BMX Ativa RR (Brasmax) cultivar had a determinate growth type and relative maturity group (RMG) equal to 5.6, the TEC 6029 IPRO [Cooperativa Central Gaúcha Ltda. (CCGL)] cultivar had an indeterminate growth type and RMG equal to 5.7, and the BMX Potência RR (Brasmax) cultivar had an indeterminate growth type and RMG equal to 6.7. The conventional inoculation contained bacteria of the genus Bradyrhizobium, B. japonicum strain CPAC 15 (SEMIA 5079) and B. diazoefficiens (Delamuta et al., 2013) strain CPAC 7 (SEMIA 5080) at $7 \times 10^{9}$ colony-forming units (CFU) $\mathrm{mL}^{-1}$ of a commercial product at a dose of 0.002 $\mathrm{L} \mathrm{kg}^{-1}$ seeds. The co-inoculation contained the same strains as the conventional inoculation plus Azospirillum brasilense strains $\mathrm{Ab}-\mathrm{V} 5$ and $\mathrm{Ab}-\mathrm{V} 6$ at $2 \times 10^{8} \mathrm{CFU} \mathrm{mL}^{-1}$ at the same total dose of $0.002 \mathrm{~L} \mathrm{~kg}^{-1}$ of seeds. Urea $(45 \%$ of $\mathrm{N}$ ) was used as the $\mathrm{N}$ fertilizer topdressing, and was manually applied at $0 \mathrm{~kg} \mathrm{~N}$ (without supplementation), $75 \mathrm{~kg} \mathrm{~N} \mathrm{ha}^{-1}(37.5 \mathrm{~kg}$ in V4 $+37.5 \mathrm{~kg}$ in R2), or $150 \mathrm{~kg}$ $\mathrm{N}(75 \mathrm{~kg}$ in $\mathrm{V} 4+75 \mathrm{~kg}$ in $\mathrm{R} 2)$.

Four plants were sampled to assess the number of nodules per plant (NNP, plant $\left.{ }^{-1}\right)$ and dry matter (DMP, g plant $^{-1}$ ) during stage V5 (five nodes and four fully developed trifoliate leaves), and four more plants were sampled for a similar evaluation during stage R3. All nodules present on the taproot and secondary roots larger than $2 \mathrm{~mm}$ diameter were counted. Five plants were sampled for assessing plant growth and yield during stage R8 (full ripening of $95 \%$ pods). The number of pods per plant (NPP, plant ${ }^{-1}$ ) was counted, and pods of one, two and three seeds were selected to estimate the number of seeds per pod (NSPo, pod $\left.{ }^{-1}\right)$. The harvested area comprised $5 \mathrm{~m}$ within three central rows $\left(6.75 \mathrm{~m}^{2}\right)$, and the two external rows and $1 \mathrm{~m}$ of the ends of the rows were the borders. The plants were threshed and cleaned for the measurement and correction of the seed moisture (base 13\%), the estimated grain yield (GY, Mg ha-1), and the thousand seed weight (TSW, g).

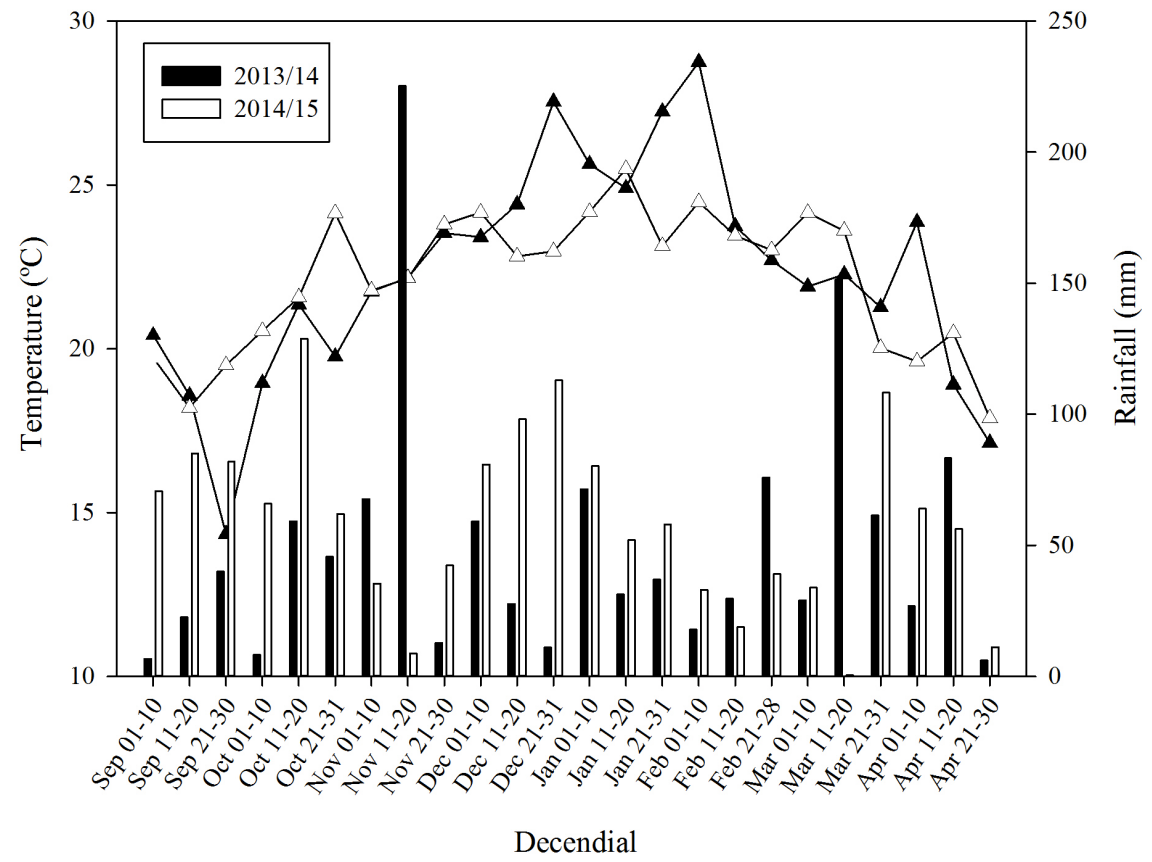

Figure 1: Mean temperatures $\left({ }^{\circ} \mathrm{C}\right)$ and accumulated precipitation $(\mathrm{mm})$ during the experimental period in $2013 / 14$ and 2014/15. 
The data were verified and met the mathematical model assumptions. A subsequent analysis of variance (F-test) was conducted, and when a significant difference was confirmed, a mean comparison test was applied [ScottKnott $(\alpha \leq 0.05)]$ using the Sisvar ${ }^{\circledR}$ statistical software (Ferreira, 2011).

\section{RESULTS AND DISCUSSION}

The analysis of variance indicated that triple, double and main effect interactions were present and were significant for each measured variable (Table 1). For the sowing on October 15, 2013, the data for cultivar TEC 6029 were not reported because of problems with the germination of the seed lot, so this cultivar was discarded.

The number of nodules per plant was significantly affected by the inoculum type in the two sample stages tested. In V5, nodulation was not significantly different between the two inoculum types for most treatment combinations, but co-inoculation provided occasional significant increases, such as the best performance when nitrogen was not supplied (Table 2).

To ensure satisfactory nodulation, at least $1 \times 10^{4}$ colony-forming units (CFU) seed ${ }^{-1}$ of rhizobia should be provided, and a proportional increase in the number and mass of nodules, yield and $\mathrm{N}$ content in the grain occurs when this dose it increased to $1 \times 10^{7}$ (Albareda et al., 2009). To achieve this level, inoculants at concentrations of approximately $10^{8}-10^{9} \mathrm{CFU}$ per gram or $\mathrm{mL}$ (peat or liquid) of product is required (Hartley et al., 2005).
According to the current legislation in Brazil, the bacterial load in an inoculum should be $1 \times 10^{9} \mathrm{CFU}$ per gram or $\mathrm{mL}$ of product for Bradyrhizobium and $1 \times 10^{8} \mathrm{CFU}$ per gram or $\mathrm{mL}$ of product for Azospirillum brasilense (Hungria, Nogueira and Araújo, 2015). Both inoculants that were used in the experimental inocula exceeded the required standard: seven-fold higher for the first inoculum and two-fold higher for the second.

Mixed inoculation has been indicated to promote the earlier occurrence of nodulation and an increase in the root system (Chibeba et al., 2015; Benintende et al., 2010). In the present study, the rapid formation of nodules in the vegetative stages of the soybean crop (V5) was demonstrated, reaching means of 5-10 more nodules plant $^{-1}$ compared to treatment with Bradyrhizobium alone. Cassán et al. (2009) observed a similar phenomenon in co-inoculated plants, confirming that the two bacterial genera are capable of excreting indole-3-acetic acid (IAA), gibberellic acid and zeatin in sufficient concentrations to cause morphological and physiological changes in young tissues.

The $\mathrm{N}$ fertilizer topdressing did not affect nodulation, suggesting that mineral $\mathrm{N}$ is not harmful during later stages of the growing season. In experiments with diazotrophic bacteria, it is usual that one of the control treatments has added $\mathrm{N}$, usually as high doses of urea immediately after sowing and during flowering, which causes a lower number and mass of nodules (Campos; Gnatta, 2006; Hungria; Campo; Mendes, 2003). According

Table 1: Summary of analysis of variance for the variables in each periods evaluated.

\begin{tabular}{|c|c|c|c|c|c|}
\hline \multirow{2}{*}{\multicolumn{2}{|c|}{$\begin{array}{c}\text { Agricultural year } \\
\text { Sowing date }\end{array}$}} & \multicolumn{2}{|c|}{$2013 / 14$} & \multicolumn{2}{|c|}{$2014 / 15$} \\
\hline & & October 15, 2013 & November 11, 2013 & October 28,2014 & November 15, 2014 \\
\hline Var $^{1}$ & $\mathrm{PS}^{2}$ & \multicolumn{4}{|c|}{ Type of interaction and factors ${ }^{3}$} \\
\hline NNP & V5 & $C v \times \ln \times N$ & In; Cv x N & $\ln \times N ; C v \times \ln$ & $C v \times \ln \times N$ \\
\hline DMP & V5 & $\mathrm{Cv} \times \mathrm{N} ; \operatorname{In} \times \mathrm{N}$ & $C v ; \ln \times N$ & $C v \times \ln \times N$ & $\mathrm{Cv} \times \mathrm{N} ; \operatorname{In} \times \mathrm{N}$ \\
\hline NNP & R3 & $\mathrm{CV} \times \mathrm{N} ; \operatorname{In} \times \mathrm{N}$ & $\mathrm{Cv} \times \ln \times \mathrm{N}$ & $C v \times \ln \times N$ & $\mathrm{Cv} \times \mathrm{In} ; \mathrm{Cv} \times \mathrm{N}$ \\
\hline DMP & R3 & $\mathrm{Cv} \times \ln \times \mathrm{N}$ & $\mathrm{Cv} \times \mathrm{N} ; \operatorname{In} \times \mathrm{N}$ & $\mathrm{Cv} \times \ln \times \mathrm{N}$ & $\mathrm{Cv} \times \mathrm{N} ; \operatorname{In} \times \mathrm{N}$ \\
\hline NPP & R8 & $\mathrm{Cv} \times \ln \times \mathrm{N}$ & $\mathrm{Cv} \times \ln \times \mathrm{N}$ & $\mathrm{Cv} \times \ln \times \mathrm{N}$ & $\mathrm{Cv} \times \ln \times \mathrm{N}$ \\
\hline NSPo & R8 & C & $C v \times \ln \times N$ & C & C \\
\hline TSW & $\mathrm{R} 8$ & $C v \times \ln \times N$ & $C v \times \ln \times N$ & $C v \times \ln \times N$ & $C v \times \ln \times N$ \\
\hline GY & R8 & $C v \times \ln \times N$ & $\ln \times N ; C v \times \ln$ & $C v \times \ln \times N$ & $C v \times \ln \times N$ \\
\hline
\end{tabular}

${ }^{1}$ Variables: number of nodules per plant (NNP, plant-1 ${ }^{-1}$ ) dry matter plants (DMP, g plant $\left.{ }^{-1}\right)$, number of pods per plant (NPP, plant $\left.{ }^{-1}\right)$; number of seeds per pod (NSPo, $\left.\operatorname{pod}^{-1}\right)$, thousand seed weight (TGW, g), and grain yield $\left(\mathrm{GY}, \mathrm{Mg} \mathrm{ha}^{-1}\right) ;{ }^{2} \mathrm{phenological}^{2}$ stage (Fehr et al., 1971): V5 (five node and four fully developed trifoliate leaf); R3 (early pod formation); R8 (full ripening of 95\% of pods); ${ }^{3}$ Factors: cultivars (CV); type of inoculation (In); type of nitrogen topdressing (N). 
to Bottomley and Myrold (2007), some mineral forms of $\mathrm{N}$ in the soil such as nitrate $\left(\mathrm{NO}_{3}^{-}\right)$and ammonium $\left(\mathrm{NH}_{4}^{+}\right)$can inhibit nodule formation and degrade already formed nodules, affecting BNF. In this study, $\mathrm{N}$ application during the vegetative stage V4 did not affect symbiosis by reducing the number of nodules per plant in V5. Aratani et al. (2008) have shown that nitrogen fertilization did not harm nodulation nor interfere with nodule dry matter.
Nodulation in R3 showed anomalous behavior, complicating the interpretation of the results (Table 2). The addition of urea ( 75 or $150 \mathrm{~kg}$ of $\mathrm{N} \mathrm{ha}^{-1}$ ) tended to decrease the number of nodules. The highest mean number of nodules that occurred in the treatment without urea is noteworthy, and indicated that mineral $\mathrm{N}$ provided during the reproductive stage was detrimental to nodulation. Nodulation should be better exploited because a trend of breeding cultivars

Table 2: Number of nodules per plant (NNP, plant ${ }^{-1}$ ) observed in V5 and R3 depending on the type of inoculation, cultivars and nitrogen topdressing.

\begin{tabular}{|c|c|c|c|c|c|c|}
\hline \multirow[t]{2}{*}{ Type of inoculation ${ }^{2}$} & \multicolumn{3}{|c|}{ Conventional inoculation } & \multicolumn{3}{|c|}{ Co-inoculation } \\
\hline & & & ---------- & 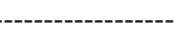 & 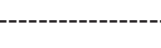 & ------- \\
\hline \multirow[t]{2}{*}{ Sowing } & \multicolumn{6}{|c|}{ October 15, 2013} \\
\hline & \multicolumn{3}{|c|}{ kg N ha-13 } & \multicolumn{3}{|c|}{$\mathrm{kg} \mathrm{N} \mathrm{ha}^{-1}$} \\
\hline Cultivar $^{1}$ & 0 & 75 & 150 & 0 & 75 & 150 \\
\hline Ativa & $\beta 64.0 \mathrm{bB}^{*}$ & $\beta 55.7$ aB & a 74.5 aA & a $83.5 \mathrm{bA}$ & a $77.4 \mathrm{aA}$ & a 72.2 aA \\
\hline Potência & $\beta 75.1 \mathrm{aA}$ & $\mathrm{a} 63.8 \mathrm{aB}$ & a 80.6 aA & a $112.6 \mathrm{aA}$ & $\mathrm{a} 67.4 \mathrm{aB}$ & $\beta 59.3 \mathrm{bB}$ \\
\hline Average $=78.33$ & & 68.9 & & & 78.7 & \\
\hline \multicolumn{7}{|l|}{$\mathrm{CV} \%=9.81$} \\
\hline Sowing & \multicolumn{6}{|c|}{ November 15, 2014} \\
\hline Ativa & a 57.4 aA & $\mathrm{a} 44.8 \mathrm{bA}$ & a 53.2 aA & a $57.7 \mathrm{bA}$ & a 54.6 aA & a $42.6 \mathrm{bA}$ \\
\hline TEC 6029 & $\beta 66.2 \mathrm{aA}$ & a 65.5 aA & $\beta 52.8$ aA & a 80.9 aA & a 65.4 aA & a 70.3 aA \\
\hline Potência & a 66.7 aA & a $63.4 \mathrm{aA}$ & $\beta 55.3 \mathrm{aA}$ & a $65.8 \mathrm{bA}$ & a 62.9 aA & a $70.8 \mathrm{aA}$ \\
\hline Average $=60.93$ & & 58.4 & & & 63.4 & \\
\hline $\mathrm{CV} \%=16.62$ & & & & & & \\
\hline
\end{tabular}

November 11, 2013

\begin{tabular}{|c|c|c|c|c|c|c|}
\hline \multirow[b]{2}{*}{ Ativa } & & & & & & \\
\hline & a $165.1 \mathrm{aA}$ & a $131.4 \mathrm{aB}$ & a $131.5 \mathrm{aB}$ & a $118.0 \mathrm{aA}$ & $\beta 96.9 \mathrm{bB}$ & $\beta 99.1 \mathrm{bB}$ \\
\hline TEC 6029 & a 120.7 aA & a 104.3 bA & $\beta 107.8 \mathrm{bA}$ & a 117.3 aA & a 131.7 aA & a 137.8 aA \\
\hline Potência & a 113.3 aA & a 91.7 bA & a $105.7 \mathrm{bA}$ & a 132.5 aA & a 104.6 bB & a $118.5 \mathrm{aB}$ \\
\hline Average $=118.87$ & & 117.37 & & & 119.1 & \\
\hline \multicolumn{7}{|l|}{$\mathrm{CV} \%=11.85$} \\
\hline Sowing & \multicolumn{6}{|c|}{ October 28, 2014} \\
\hline Ativa & a 95.7 aA & a 69.3 bB & a 83.7 aA & B $70.8 \mathrm{cA}$ & a 70.6 bA & $\beta \quad 65.3 \mathrm{bA}$ \\
\hline TEC 6029 & a 111.6 aA & $\beta 85.0 \mathrm{aB}$ & a $92.2 \mathrm{aB}$ & a 125.7 aA & a 99.2 aB & a $103.3 \mathrm{aB}$ \\
\hline Potência & a 132.0 aA & a 110.6 aB & $\beta 78.4 \mathrm{aC}$ & $\beta 101.1 \mathrm{bA}$ & a 99.8 aA & a $101.2 \mathrm{aA}$ \\
\hline Average $=94.21$ & \multirow{2}{*}{\multicolumn{3}{|c|}{93,0}} & \multicolumn{3}{|c|}{95,38} \\
\hline $\mathrm{CV} \%=12.06$ & & & & & & \\
\hline
\end{tabular}

${ }^{1}$ Cultivars (CV); ${ }^{2}$ Types of inoculation (In); ${ }^{3}$ Nitrogen topdressing $(\mathrm{N})$; * $m e a n s$ followed by the same letter are not statistically different from each other by the Scott-Knott test ( $a \leq 0.05$ ). Lowercase letters are observed in the column (" $\mathrm{Cv}$ " within each level of the "In $x N^{\prime \prime}$ ), uppercase letters are observed in the row ("N" within each level of the "Cv $x$ In"), Greek letters are observed among the same combination of cells ("In" within each level of the " $\mathrm{CV} \times \mathrm{N}$ "). 
that produce grain with higher protein content exists. To accomplish this, plants should be selected for maximum BNF (Santos et al., 2013). A higher nodule number of is an indication of efficient symbiosis. Over $40 \%$ of the grain yield is correlated with the nodulation component of soybean cultivars (Brandalero; Peixoto; Ralisch, 2009), emphasizing the importance of effective inoculation.

The importance of shoot dry matter has been reported by Souza et al. (2008), who have observed a significant correlation between dry matter and total $\mathrm{N}$ accumulated in shoots as well as ureide $\mathrm{N}$. The plant dry matter sampled in V5 showed little or no effects from the application of urea (Table 3). Plants sowed on October 28, 2014 had dry matter means lower than those observed for the previous sowing, probably due to the establishment of a better plant stand, which meant that the plants had fewer side branches and therefore less dry matter. Dry matter in R3 was also lower on average, reinforcing the previous results (Table 3 ).

Table 3: Dry matter plant (DMP, g plant ${ }^{-1}$ ) observed in V5 and R3 depending on the type of inoculation, cultivars and nitrogen topdressing.

Type of inoculation $^{2} \quad$ Conventional inoculation $_{n}$

Sowing

November 11, 2013

\begin{tabular}{|c|c|c|c|c|c|c|}
\hline \multirow[b]{2}{*}{ Cultivar $^{1}$} & \multicolumn{3}{|c|}{$\mathrm{kg}$ of $\mathrm{N} \mathrm{ha}^{-13}$} & \multicolumn{3}{|c|}{$\mathrm{kg}$ of $\mathrm{N} \mathrm{ha}^{-1}$} \\
\hline & 0 & 75 & 150 & 0 & 75 & 150 \\
\hline Ativa & a $17.8 b B^{*}$ & a $17.5 \mathrm{aB}$ & a 20.4 aA & a $15.6 \mathrm{bB}$ & a $18.6 \mathrm{bA}$ & a $19.1 \mathrm{aA}$ \\
\hline TEC 6029 & $\beta 15.7 \mathrm{bB}$ & a $19.2 \mathrm{aA}$ & a 17.9 aA & a 20.4 aA & a 20.7 aA & a $16.4 \mathrm{bB}$ \\
\hline Potência & a 21.9 aA & a $18.4 \mathrm{aB}$ & a $20.0 \mathrm{aB}$ & $\beta 19.2 \mathrm{aA}$ & a $16.6 \mathrm{bA}$ & a $18.8 \mathrm{aA}$ \\
\hline Average $=18.56$ & & 18.8 & & & 18.4 & \\
\hline \multicolumn{7}{|l|}{$\mathrm{CV} \%=9.71$} \\
\hline Sowing & \multicolumn{6}{|c|}{ October 28, 2014} \\
\hline Ativa & a 4.2 bA & $\beta 4.4 \mathrm{bA}$ & $\beta 4.7 \mathrm{aA}$ & $a 4.7 \mathrm{bA}$ & a 5.2 bA & a 5.7 aA \\
\hline TEC 6029 & $\beta 4.6 \mathrm{bA}$ & $\beta 5.4 \mathrm{aA}$ & a 4.7 aA & a $6.2 \mathrm{aA}$ & a $6.2 \mathrm{aA}$ & a $5.1 \mathrm{aB}$ \\
\hline Potência & a 5.6 aA & a 5.3 aA & $\beta 5.1 \mathrm{aA}$ & a 5.2 bA & a $5.5 \mathrm{bA}$ & a $5.9 \mathrm{aA}$ \\
\hline Average $=5.23$ & \multirow{2}{*}{\multicolumn{3}{|c|}{4.9}} & \multirow{2}{*}{\multicolumn{3}{|c|}{5,5}} \\
\hline CV $\%=10.61$ & & & & & & \\
\hline
\end{tabular}

\begin{tabular}{|c|c|c|c|c|c|c|}
\hline \multirow[b]{3}{*}{ Ativa } & \multicolumn{6}{|c|}{ 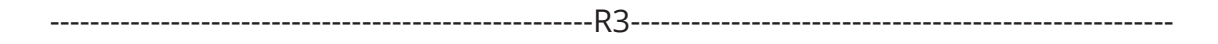 } \\
\hline & \multicolumn{6}{|c|}{ October 15, 2013} \\
\hline & a 39.7 bA & a 43.1 aA & a $39.0 \mathrm{bA}$ & a 44.0 aA & a 41.6 aA & a $43.3 \mathrm{bA}$ \\
\hline Potência & a $62.1 \mathrm{aA}$ & a $45.7 \mathrm{aB}$ & a 62.4 aA & $\beta 41.1 \mathrm{aB}$ & a $48.2 \mathrm{aB}$ & a 68.0 aA \\
\hline Average $=48.19$ & & 48.7 & & & 47.7 & \\
\hline \multicolumn{7}{|l|}{$\mathrm{CV} \%=11.61$} \\
\hline Sowing & \multicolumn{6}{|c|}{ October 28, 2014} \\
\hline Ativa & a 24.6 aA & a 24.7 aA & a $20.2 b B$ & $\beta 19.6 \mathrm{bA}$ & $\beta 20.6 \mathrm{bA}$ & a 20.9 aA \\
\hline TEC 6029 & $\beta 22.0 \mathrm{aA}$ & a $23.3 \mathrm{aA}$ & a 24.8 aA & a 26.8 aA & a $19.4 \mathrm{bB}$ & a $23.5 \mathrm{aA}$ \\
\hline Potência & a 26.1 aA & a $25.2 \mathrm{aA}$ & a $25.2 \mathrm{aA}$ & a $24.1 \mathrm{aA}$ & a 25.6 aA & a $22.3 \mathrm{aA}$ \\
\hline Average $=23.20$ & \multirow{2}{*}{\multicolumn{3}{|c|}{24.0}} & \multirow{2}{*}{\multicolumn{3}{|c|}{22.5}} \\
\hline $\mathrm{CV} \%=12.28$ & & & & & & \\
\hline
\end{tabular}

${ }^{1}$ Cultivars (Cv); ${ }^{2}$ Types of inoculation (In); ${ }^{3}$ Nitrogen topdressing $(\mathrm{N}) ;{ }^{*}$ means followed by the same letter are not statistically different from each other by the Scott-Knott test ( $a \leq 0.05)$. Lowercase letters are observed in the column ("Cv" within each level of the "In $x N^{\prime \prime}$ ), uppercase letters are observed in the row ("N" within each level of the "Cv $x$ In"), Greek letters are observed among the same combination of cells ("In" within each level of the " $\mathrm{Cv} \times \mathrm{N}^{\prime}$ ). 
Co-inoculated plants sowed on October 28, 2014 and sampled in V5 showed the highest average dry matter. The results of Groppa, Zawoznik and Tomaro (1998) corroborate this observation, indicating the increased production of total dry matter compared to conventional inoculation. Root dry matter can greatly contribute to the increase in the total dry matter of plants. Juge et al. (2012) showed significant differences in the total plant mass, but the shoot dry matter was not different. High root dry matter coincides with a high rate of BNF that encourages further root proliferation and the subsequent use of water and nutrients, so sugar production is not limited.

The highest average number of pods ( 72 pods plant $^{-1}$ ) was observed for the sowing of November 15, 2014. (Table 4). The number of pods has a strong correlation with the yield (Dalchiavon; Carvalho, 2012), when favorable conditions for grain filling occur. These results did not occur in the treatments with higher yields, which can be explained by the evaluation methodology that considers even pods containing only a single seed.

Table 4: Number of pods per plant (NPP, plant ${ }^{-1}$ ) observed in R8 depending on the type of inoculation, cultivars and nitrogen topdressing.

\begin{tabular}{|c|c|c|c|c|c|c|}
\hline \multirow{3}{*}{$\begin{array}{c}\text { Sowing } \\
\text { Type of inoculation }{ }^{2} \\
\text { Cultivar }^{1}\end{array}$} & \multicolumn{6}{|c|}{ October 15, 2013} \\
\hline & \multicolumn{3}{|c|}{$\begin{array}{l}\text { Conventional inoculation } \\
\qquad \mathrm{kg} \text { of } \mathrm{N} \mathrm{ha}^{-13}\end{array}$} & \multicolumn{3}{|c|}{$\begin{array}{l}\text { Co-inoculation } \\
\text { kg of } \mathrm{N} \mathrm{ha}^{-1}\end{array}$} \\
\hline & 0 & 75 & 150 & 0 & 75 & 150 \\
\hline Ativa & a $80.9 a^{*}$ & a 90.9 aB & a 72.7 aA & a 78.4 aA & $\beta 71.3 \mathrm{aA}$ & a 70.1 aA \\
\hline Potência & a $54.5 \mathrm{bB}$ & a 64.2 bA & a 69.0 aA & a $59.8 \mathrm{bA}$ & a 63.4 aA & $\beta 51.5 \mathrm{bA}$ \\
\hline Average $=68.90$ & & 72.0 & & & 67.8 & \\
\hline \multicolumn{7}{|l|}{$\mathrm{CV} \%=10.94$} \\
\hline Sowing & \multicolumn{6}{|c|}{ November 11, 2013} \\
\hline Ativa & $\beta 56.3$ aB & a 69.2 aA & a 66.0 aA & a 66.7 aA & a 66.8 aA & a 63.9 aA \\
\hline TEC 6029 & a 50.2 bB & a 56.4 bA & $\beta 51.1 \mathrm{bB}$ & $\beta 61.3 \mathrm{aA}$ & a $62.0 \mathrm{aA}$ & a 59.0 aA \\
\hline Potência & a 46.4 bB & a 40.1 cC & a $52.3 \mathrm{bA}$ & $\beta 37.9 \mathrm{bA}$ & a 40.3 bA & $\beta 42.8 \mathrm{bA}$ \\
\hline Average $=54.88$ & & 54.2 & & & 55.6 & \\
\hline \multicolumn{7}{|l|}{$\mathrm{CV} \%=7.25$} \\
\hline Sowing & \multicolumn{6}{|c|}{ October 28, 2014} \\
\hline Ativa & a 45.0 aA & a 40.6 aA & a 48.3 aA & $\beta 36.4$ bA & a 40.8 bA & B 39.9 aA \\
\hline TEC 6029 & $\mathrm{a} 42.2 \mathrm{aB}$ & $\beta 32.8 \mathrm{bc}$ & a 49.2 aA & a 48.0 aA & a 49.5 aA & $\beta 41.8 \mathrm{aB}$ \\
\hline Potência & a 39.0 aA & a $42.8 \mathrm{aA}$ & a $42.3 \mathrm{aA}$ & a $41.9 \mathrm{bA}$ & a $41.4 \mathrm{bA}$ & a $47.0 \mathrm{aA}$ \\
\hline Average $=42.73$ & & 42.5 & & & 43.0 & \\
\hline \multicolumn{7}{|l|}{ CV \% = 10.87} \\
\hline Sowing & \multicolumn{6}{|c|}{ November 15, 2014} \\
\hline Ativa & a $50.7 \mathrm{bA}$ & a 49.4 bA & a $48.5 \mathrm{cA}$ & a $53.2 \mathrm{cA}$ & a $41.7 \mathrm{bA}$ & a $42.8 \mathrm{cA}$ \\
\hline TEC 6029 & $\beta 61.2 \mathrm{bB}$ & $\beta 57.3$ bB & $\mathrm{a} 81.2 \mathrm{bA}$ & a $75.3 \mathrm{bB}$ & a 90.3 aA & a $77.2 \mathrm{bB}$ \\
\hline Potência & $\beta 77.4 \mathrm{aB}$ & a $101.7 \mathrm{aA}$ & a 105.4 aA & a $107.1 \mathrm{aA}$ & $\beta 83.4 \mathrm{aB}$ & $\beta 92.4 \mathrm{aB}$ \\
\hline Average $=72.04$ & \multirow{2}{*}{\multicolumn{3}{|c|}{70.3}} & \multicolumn{3}{|c|}{73.7} \\
\hline CV \% = 12.00 & & & & & & \\
\hline
\end{tabular}

${ }^{1}$ Cultivars (CV); ${ }^{2}$ Types of inoculation (In); ${ }^{3}$ Nitrogen topdressing $(\mathrm{N}) ;{ }^{*}$ means followed by the same letter are not statistically different from each other by the Scott-Knott test ( $a \leq 0.05)$. Lowercase letters are observed in the column ("Cv" within each level of the "In $x \mathrm{~N}^{\prime \prime}$ ), uppercase letters are observed in the row ("N" within each level of the "CV $\mathrm{x} I \mathrm{n}^{\prime}$ ), Greek letters are observed among the same combination of cells ("In" within each level of the " $\mathrm{Cv} \times \mathrm{N}$ "). 
The cultivar BMX Potência presented the highest average number of seeds per pod, (Table 5). This yield component had the least variability, even in different tillage situations, which can be attributed to breeding for soybeans with an average of two seeds per pod (Mundstock; Thomas, 2005). For the experiments in this study, the overall average ranged from 2.15 to 2.36 seeds per pod, and differed with the sowing time.

Along with the number of seeds per pod, seed mass is also a characteristic for each cultivar, but the number can change depending on the environmental conditions and tillage (Silva et al., 2011b). Co-inoculation achieved the best average for all tested cultivars, and the cultivar with the heaviest seeds was TEC 6029. The thousand seed weight was lower for the sowing on November 15, 2014, which was $142.2 \mathrm{~g}$ on average, while the average of the other three experiments was $167 \mathrm{~g}$ (Table 6). As mentioned earlier, the average of pods per plant was also highest for plants sown on this date, and this may have affected the seed filling, reducing the mass.
Effective BNF increases the seed mass, and this was demonstrated by the foliar application of cobalt and molybdenum compared to uninoculated plants that were not supplemented with the micronutrients (Silva et al., 2011a). Molybdenum is a cofactor of nitrate reductase, which increases its activity, enabling the incorporation of nitrogen by the plant (Toledo et al., 2010).

Co-inoculated plants achieved equal or superior yields compared to conventional inoculation in most of the observations, regardless of nitrogen topdressing. The average increase in the grain yield was $240 \mathrm{~kg} \mathrm{ha}^{-1}$ compared to conventional inoculation (Figure 2). The cultivars BMX Ativa, TEC 6029 and BMX Potência, showed yield increases of 6,4 and $12 \%$, respectively, when co-inoculated. The practice of co-inoculation with PGPR has increased yield. This has been shown with co-inoculation with Bacillus (Atieno et al., 2012) and A. brasilense (Hungria; Nogueira; Araújo, 2013).

Table 5: Number of seeds per pod (NSPo, pod $\left.{ }^{-1}\right)$ observed in R8 depending on the cultivar.

\begin{tabular}{ccccc}
\hline Sowing & October 15, 2013 & October 28, 2014 & December 15, 2014 & Cultivar average \\
\hline Cultivars & & & & \\
\hline Ativa & $2.05 \mathrm{~b}^{*}$ & $2.11 \mathrm{~b}$ & $2.33 \mathrm{~b}$ & 2.16 \\
TEC 6029 & ----- & $2.06 \mathrm{~b}$ & $2.28 \mathrm{c}$ & 2.17 \\
Potência & $2.39 \mathrm{a}$ & $2.28 \mathrm{a}$ & $2.48 \mathrm{a}$ & 2.38 \\
\hline Overall average & 2.22 & 2.15 & 2.36 & \\
CV \% & 2.51 & 4.25 & 2.60 & \\
\hline
\end{tabular}

*means followed by the same letter in the column do not differ statistically from each other by the Scott-Knott test $(a \leq 0.05)$.

Table 6: Thousand seed weight (TSW, g) observed in R8 depending on the type of inoculation, cultivars and nitrogen topdressing.

\begin{tabular}{|c|c|c|c|c|c|c|}
\hline \multirow{4}{*}{$\begin{array}{c}\text { Sowing } \\
\text { Type of inoculation }{ }^{2} \\
\text { Cultivar }^{1}\end{array}$} & \multicolumn{6}{|c|}{ October 15, 2013} \\
\hline & \multirow{2}{*}{\multicolumn{3}{|c|}{$\begin{array}{l}\text { Conventional inoculation } \\
\qquad \mathrm{kg} \text { of } \mathrm{N} \mathrm{ha}^{-13}\end{array}$}} & \multirow{2}{*}{\multicolumn{3}{|c|}{$\begin{array}{l}\text { Co-inoculation } \\
\text { kg of } \mathrm{N} \mathrm{ha}^{-1}\end{array}$}} \\
\hline & & & & & & \\
\hline & 0 & 75 & 150 & 0 & 75 & 150 \\
\hline Ativa & a $172 a^{*}$ & a 190 aA & a 178 aB & a 176 aB & a 189 aA & $\beta 150 \mathrm{bc}$ \\
\hline Potência & a 157 bA & a 157 bA & $a 153 b A$ & a 152 bA & a 154 bA & a 155 aA \\
\hline \multirow[t]{2}{*}{ Average $=165.72$} & & 167.8 & & & 162.7 & \\
\hline & \multicolumn{2}{|c|}{$C V \%=2.04$} & & & & \\
\hline
\end{tabular}


Table 6: Continued.

\begin{tabular}{|c|c|c|c|c|c|c|}
\hline \multirow{2}{*}{$\frac{\text { Sowing }}{\text { Ativa }}$} & \multicolumn{6}{|c|}{$18 / 11 / 2013$} \\
\hline & $\beta 148$ св & a $158 \mathrm{cA}$ & B $156 \mathrm{cA}$ & a $161 \mathrm{bB}$ & a 153 cC & a 175 aA \\
\hline TEC 6029 & a 180 aA & a 183 aA & a 180 aA & $\beta 171$ aA & $\beta 168 \mathrm{bA}$ & $\beta 168 \mathrm{bA}$ \\
\hline Potência & $\beta 168 \mathrm{bA}$ & a $171 \mathrm{bA}$ & a $170 \mathrm{bA}$ & a 175 aA & a 176 aA & a $166 \mathrm{bB}$ \\
\hline Average $=168.76$ & & 168.2 & & & 168.1 & \\
\hline \multicolumn{7}{|l|}{$\mathrm{CV} \%=2.62$} \\
\hline Sowing & \multicolumn{6}{|c|}{ 28/10/2014 } \\
\hline Ativa & $\beta 153 \mathrm{bB}$ & a 176 bA & a $171 \mathrm{bA}$ & a $179 \mathrm{bA}$ & a $167 \mathrm{bB}$ & a $163 \mathrm{bB}$ \\
\hline TEC 6029 & a 188 aA & a 195 aA & B 184 aA & a 190 aA & a $196 \mathrm{aA}$ & a 199 aA \\
\hline Potência & a $136 \mathrm{cA}$ & a $130 \mathrm{cA}$ & a $140 \mathrm{cA}$ & a $139 \mathrm{cA}$ & a $137 \mathrm{cA}$ & a $140 \mathrm{cA}$ \\
\hline Average $=166.29$ & & 163.7 & & & 167.8 & \\
\hline \multicolumn{7}{|l|}{$\mathrm{CV} \%=4.04$} \\
\hline Sowing & \multicolumn{6}{|c|}{$15 / 12 / 2014$} \\
\hline Ativa & a $136 \mathrm{bA}$ & a $133 \mathrm{bA}$ & a $133 b A$ & a $135 \mathrm{bA}$ & a $135 \mathrm{bA}$ & a $135 b A$ \\
\hline TEC 6029 & a 169 aA & $\beta 170$ aA & a 166 aA & a 170 aA & a 176 aA & a 171 aA \\
\hline Potência & $\beta 113 c B$ & a $123 \mathrm{cA}$ & $\beta 113 c B$ & a $128 \mathrm{cA}$ & a $122 \mathrm{cB}$ & a $121 \mathrm{cB}$ \\
\hline Average $=142.20$ & & 139.6 & & & 143.7 & \\
\hline $\mathrm{CV} \%=2.85$ & & & & & & \\
\hline
\end{tabular}

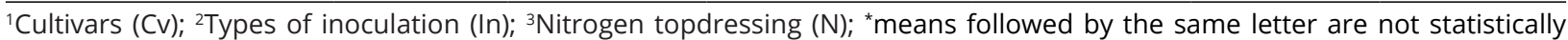
different from each other by the Scott-Knott test ( $\mathrm{a} \leq 0.05)$. Lowercase letters are observed in the column ("Cv" within each level of the "In $x \mathrm{~N}^{\prime \prime}$ ), uppercase letters are observed in the row ("N" within each level of the " $\mathrm{Cv} x \mathrm{In}^{\prime}$ ), Greek letters are observed among the same combination of cells ("In" within each level of the " $\mathrm{C} v \times \mathrm{N}$ ").

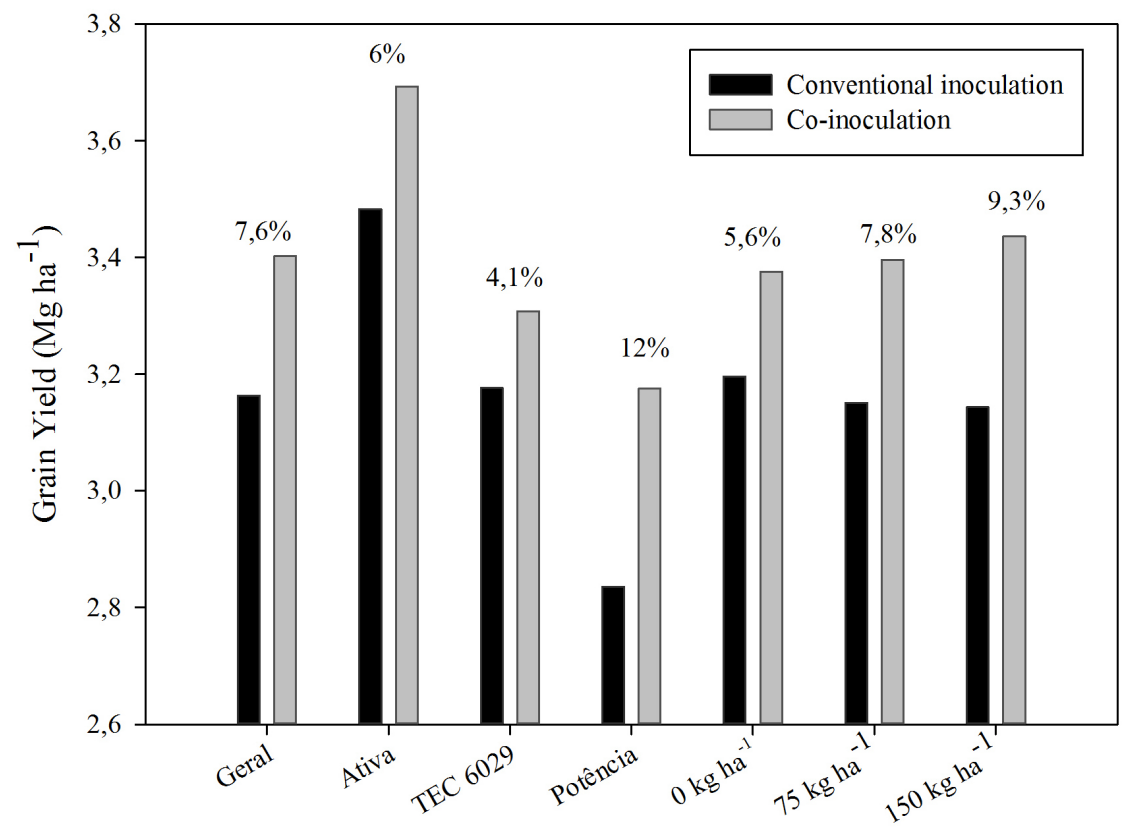

Treatments

Figure 2: Effect of inoculation type on grain yield $\left(\mathrm{Mg} \mathrm{ha}^{-1}\right)$ and percentage of increase. Average data of all experiments. 
Co-inoculated treatments combined with $\mathrm{N}$ fertilizer topdressing showed two types of responses, both in favor of the higher dose of fertilizer, but sometimes without statistical significance. (Table 7). The $150 \mathrm{~kg} \mathrm{~N}^{-1}$ treatment stood out mainly during the wettest season for cultivars with an indeterminate growth type. A nonsignificant response to the urea topdressing prevailed in the dry season, which decreased yield. In contrast, conventional inoculation showed no response to $\mathrm{N}$ fertilizer topdressing, even with higher water availability conditions. This suggests that co-inoculation produces interactions between the microorganisms, maximizing the utilization of $\mathrm{N}$ available for absorption in the mineral form.

The economic feasibility of the use of $150 \mathrm{~kg}$ $\mathrm{N} \mathrm{ha}^{-1}$ in co-inoculated seeds equates to approximately $333.33 \mathrm{~kg}$ urea $\mathrm{ha}^{-1}$. The average increase was $300 \mathrm{~kg}$ grain ha-1 for indeterminate cultivars. Therefore, such a practice would become economically viable only when the fertilizer is cheaper than usual and transportation, storage and the cost of the application of fertilizer should also be considered.

An analysis of the results obtained for the other variables related to the yield implies that the application of nitrogen fertilizer is unnecessary. On average for all cultivars tested, the vegetative stages V4-V5 precedes a large crop "draining" stage followed by flowering (R1). Similarly, the formation of pods begins in the R2-R3 stage and grain filling (R5) immediately follows. Split nitrogen topdressing applied during those so-called "critical" periods for the crop did not corresponded to a yield increase. This result agrees with the results of Aratani et al. (2008) and Mendes et al. (2008), who tested nitrogen topdressing in soybeans independent of the application time, both in the vegetative and in reproductive stages, which did not increase yield compared to a treatment without nitrogen application.

Table 7: Grains yield (GY, Mg ha-1) observed in R8 depending on the type of inoculation, cultivars and nitrogen topdressing.

\begin{tabular}{|c|c|c|c|c|c|c|}
\hline Sowing & \multicolumn{6}{|c|}{ October 15, 2013} \\
\hline Type of inoculation ${ }^{2}$ & \multirow{2}{*}{\multicolumn{3}{|c|}{$\begin{array}{l}\text { Conventional inoculation } \\
\qquad \mathrm{kg} \mathrm{N} \mathrm{ha-13}^{-13}\end{array}$}} & \multirow{2}{*}{\multicolumn{3}{|c|}{$\begin{array}{l}\text { Co-inoculation } \\
\text { kg N ha-1 }\end{array}$}} \\
\hline & & & & & & \\
\hline Cultivar $^{1}$ & 0 & 75 & 150 & 0 & 75 & 150 \\
\hline Ativa & $\beta 2.92{a B^{*}}^{*}$ & a 3.88 aA & a 3.24 aB & a 3.66 aA & $\beta 3.15$ aB & a $3.36 \mathrm{aB}$ \\
\hline Potência & a 3.00 aA & $\beta 2.70 \mathrm{bA}$ & $\beta 2.32 \mathrm{bB}$ & a $3.14 \mathrm{bA}$ & a 3.15 aA & $\mathrm{a} 2.80 \mathrm{bA}$ \\
\hline Average $=3.11$ & & 3.01 & & & 3.21 & \\
\hline \multicolumn{7}{|l|}{ CV \% = 8.29} \\
\hline Sowing & \multicolumn{6}{|c|}{ October 28, 2014} \\
\hline Ativa & a 3.73 aA & a 3.70 aA & a 3.78 aA & a $3.97 \mathrm{aA}$ & a 3.86 aA & a $3.62 \mathrm{aA}$ \\
\hline TEC 6029 & a $2.88 \mathrm{bA}$ & a $2.68 \mathrm{cA}$ & $\beta 2.45 c A$ & a $2.77 \mathrm{cB}$ & a $2.97 \mathrm{cB}$ & a 3.21 bA \\
\hline Potência & $\beta 2.75 \mathrm{bA}$ & $\beta 3.03 \mathrm{bA}$ & $\beta 2.98 \mathrm{bA}$ & $\mathrm{a} 3.18 \mathrm{bA}$ & $\mathrm{a} 3.47 \mathrm{bA}$ & a $3.35 \mathrm{bA}$ \\
\hline Average $=3.24$ & \multirow{2}{*}{\multicolumn{3}{|c|}{3.11}} & \multicolumn{3}{|c|}{3.38} \\
\hline \multicolumn{4}{|l|}{ CV \% $=7.20$} & & & \\
\hline Sowing & \multicolumn{6}{|c|}{ November 15, 2014} \\
\hline Ativa & a 3.65 aA & $\beta 3.68$ aA & a 3.77 aA & a $3.67 \mathrm{aB}$ & a $4.01 \mathrm{aA}$ & a $3.94 \mathrm{aA}$ \\
\hline TEC 6029 & a 3.70 aA & a $3.71 \mathrm{aA}$ & B 3.64 aA & a $3.57 \mathrm{aB}$ & $\beta 3.43 \mathrm{bB}$ & a 3.90 aA \\
\hline Potência & a $2.94 \mathrm{bA}$ & $\beta 2.83 \mathrm{bA}$ & $\beta 2.97 \mathrm{bA}$ & a 3.05 bB & a $3.13 c B$ & a 3.31 bA \\
\hline Average $=3.49$ & \multirow{2}{*}{\multicolumn{3}{|c|}{3.43}} & \multirow{2}{*}{\multicolumn{3}{|c|}{3.56}} \\
\hline $\mathrm{CV} \%=4.12$ & & & & & & \\
\hline
\end{tabular}


The cultivar BMX Ativa RR had the highest average yield among the tested cultivars. Its behavior was little affected by the type of inoculation or nitrogen application, indicating that cultivars with a determinate growth type have greater yield stability.

\section{CONCLUSIONS}

Co-inoculation (Bradyrhizobium spp + Azospirillum spp.) increased yield compared to inoculation with Bradyrhizobium spp. alone, exemplified by increases of 6, 4 and 12\%, respectively in Ativa, TEC 6029 and BMX Potência. The application of a urea topdressing (150 kg of $\mathrm{N} \mathrm{ha}^{-1}$ ) in the two indeterminate cultivars increased yield, but without a financial return. The cultivars tested, when inoculated conventionally, did not respond positively to urea application. Most of the observed variables showed no increase with supplied urea, which is therefore unnecessary.

\section{ACKNOWLEDGMENTS}

To the National Council for Scientific and Technological Development (CNPq), for the Productivity Grant, Scientific Initiation Scholarship and Total Biotecnologia Ltda.

\section{REFERENCES}

ALBAREDA, M. et al. Soybean inoculation: Dose, $N$ fertilizer supplementation and rhizobia persistence in soil. Field Crop Research. 113(3):353-356, 2009.

ARATANI, R. G. et al. Adubação nitrogenada em soja na implantação do sistema plantio direto. Bioscience Journal. 24(3):31-38, 2008.

ATIENO, M. et al. Efficiency of different formulations of Bradyrhizobium japonicum and effect of co-inoculation of Bacillus subtilis with two strains of Bradyrhizobium japonicum. World Journal of Microbiology and Biotechnology. 28(7):2541-2550, 2012.

BASHAN, Y.; BASHAN, L. E de. How the plant growth-promoting bacterium Azospirillum promotes plant growth - A critical assessment. Advances in Agronomy. 108(2):77-136, 2010.

BENINTENDE, S. W. et al. Comparación entre coinoculación com Bradyrhizobium japonicum y Azospirillum brasilense e inoculación simple con Bradyrhizobium japonicum en la nodulación, crecimiento y acumulación de $\mathrm{N}$ en el cultivo de soja. Agriscientia. 27(2):71-77, 2010.

BOTTOMLEY, P. J.; MYROLD, D. D. Biological N inputs. In: PAUL, E. A. (Ed.). Soil microbiology, ecology and biochemistry. 3. ed. Oxford: Academic Press, 2007. p.365-388.

BRANDALERO, E. M.; PEIXOTO, C. P.; RALISCH, R. Nodulação de cultivares de soja e seus efeitos no rendimento de grãos. Semina: Ciências Agrárias. 30(3):581-588, 2009.

CAMPOS, B. C.; GNATTA, V. Inoculantes e fertilizantes foliares na soja em área de populações estabelecidas de Bradyrhizobium sob sistema plantio direto. Revista Brasileira de Ciência do Solo. 30(1):69-76, 2006.

CASSÁN, F. et al. Azospirillum brasilense Az39 and Bradyrhizobium japonicum E109, inoculated singly or in combination, promote seed germination and early seedling growth in corn (Zea mays L.) and soybean (Glycine max L.). European Journal of Soil Biology. 45(1):28-35, 2009.

CHIBEBA, A. M. et al. Co-inoculation of soybean with Bradyrhizobium and Azospirillum promotes early nodulation. American Journal of Plant Sciences. 6(10):1641-1649, 2015.

DALCHIAVON, F. C.; CARVALHO, M. P. Correlação linear e espacial dos componentes de produção e produtividade da soja. Semina: Ciências Agrárias. 33(2):541-552, 2012.

DARDANELLI, M. S. et al. Effect of Azospirillum brasilense coinoculated with Rhizobium on Phaseolus vulgaris flavonoids and nod factor production under salt stress. Soil Biology \& Biochemistry. 40(11):2713-2721, 2008.

DELAMUTA, J. R. M. et al. Polyphasic evidence supporting the reclassification of Bradyrhizobium japonicum group la strains as Bradyrhizobium diazoefficiens sp. nov. International Journal of Systematic and Evolutionary Microbiology. 63(9):3342-3351, 2013.

DEAKER, R. et al. Legume seed inoculation technology - A review. Soil Biology \& Biochemistry. 36(1):1275-1288, 2004.

EMPRESA BRASILEIRA DE PESQUISA AGROPECUÁRIA-EMBRAPA. Sistema Brasileiro de Classificação de Solos. 3. ed. Brasília, DF: EMBRAPA, 2013. 353p.

FEHR, W. R. C. et al. Stage of development descriptions for soybean, Glycine max (L.) Merrill. Crop Science. 11(1):929931, 1971.

FERREIRA, D. F. Sisvar: A computer statistical analysis system. Ciência e Agrotecnologia. 35(6):1039-1042, 2011.

GAN, Y. et al. Effect of fertilizer top-dressing at various reproductive stages on growth $\mathrm{N} 2$ fixation and yield of three soybean (Glycine max (L.) Merr.) genotypes. Field Crops Research. 80(2):147-155, 2003. 
GROPPA, M. D.; ZAWOZNIK, M. S.; TOMARO, M. L. Effect of coinoculation with Bradyrhizobium japonicum and Azospirillum brasilense on soybean plants. European Journal of Soil Biology. 34(2):75-80, 1998.

HARTLEY, E. J. et al. Age of peat-based lupin and chickpea inoculants in relating to quality and efficacy. Australian Journal of Experimental Agriculture. 45(3):183-188, 2005.

HAYAT, L. et al. Soil beneficial bacteria and their role in plant growth promotion: A review. Annals of Microbiology. 60(4):579-598, 2010.

HELDWEIN, A. B.; BURIOL, A. G.; STRECK, N. A. O clima de Santa Maria. Ciência \& Ambiente. 38(1):43-58, 2009.

HUNGRIA, M.; CAMPO, R. J.; MENDES, I. C. Benefits of inoculation of the common bean (Phaseolus vulgaris) crop with efficient and competitive Rhizobium tropici strains. Biology and Fertility of Soils. 39(2):88-93, 2003.

HUNGRIA, M.; NOGUEIRA, M. A.; ARAÚJO, R. S. Soybean seed co-Inoculation with Bradyrhizobium spp. and Azospirillum brasilense: A new biotechnological tool to improve yield and sustainability. American Journal of Plant Sciences. 6(6):811-817, 2015.

HUNGRIA, M.; NOGUEIRA, M. A.; ARAÚJO, R. S. Co-inoculation of soybeans and common beans with rhizobia and Azospirilla: Strategies to improve sustainability. Biology and Fertility of Soils. 49(7):791-801, 2013.

INSTITUTO NACIONAL DE METEOROLOGIA-INMET. Automatic meteorological stations data (National Meteorology Institute). Brasília, Distrito Federal, 2015. Available in: <http://www.inmet.gov.br/portal/ index.php?r=bdmep\%2Fbdmep>. Access in: August 03, 2016.

JUGE, C. et al. Growth and biochemical responses of soybean to double and triple microbial associations with
Bradyrhizobium, Azospirillum and arbuscular mycorrhizae. Applied Soil Ecology. 61(1):147-157, 2012.

MENDES, I. C. et al. Adubação nitrogenada suplementar tardia em soja cultivada em latossolos do cerrado. Pesquisa Agropecuária Brasileira. 43(8):1053-1060, 2008.

MUNDSTOCK, C. M.; THOMAS, A. L. Soja: Fatores que afetam o crescimento e o rendimento dos grãos. Departamento de plantas de Lavoura da Universidade do Rio Grande do Sul, UFRGS. Porto Alegre, 2005. 31p.

PEEL, M. C.; FINLAYSON, B. L.; MCMAHON, T. A. Updated world map of the Köppen-Geiger climate classification. Hydrology and Earth System Science. 11(5):1633-1644, 2007.

PETTER, F. A. et al. Respostas de cultivares de soja à adubação nitrogenada tardia em solos de cerrado. Revista Caatinga. 25(1):67-72, 2012.

SANTOS, M. A. et al. Mapping of QTLs associated with biological nitrogen fixation traits in soybean. Hereditas. 150(2-3):1725, 2013.

SILVA, A. F. et al. Doses de inoculante e nitrogênio na semeadura da soja em área de primeiro cultivo. Bioscience Journal. 27(3):404-412, 2011 a.

SILVA, A. F. et al. Inoculação com Bradyrhizobium e formas de aplicação de cobalto e molibdênio na cultura da soja. Agrarian. 4(12):98-104, 2011b.

SOUZA, R. A. et al. Conjunto mínimo de parâmetros para avaliação da microbiota do solo e da fixação biológica do nitrogênio pela soja. Pesquisa Agropecuária Brasileira. 43(1):83-91, 2008.

VERMA, J. P. et al. Impact of plant growth promotion rizhobacteria on crop production. International Journal of Agricultural Research. 5(11):954-983, 2010.

TOLEDO, M. Z. et al. Nodulação e atividade da nitrato redutase em função da aplicação de molibdênio em soja. Bioscience Journal. 26(6):858-864, 2010. 